\title{
The Importance of Professional Training for Establishing Psychological Health Workers
}

\author{
Doct. Student Dukata Radoja
}

University Europian of Tirana

Abstract

Training is an important part of modern European healthcare services and is often cited as a way to improve care quality. Health workers constantly participate in training aimed at enhancing their professional, although often noted lack of training adapted to their specific needs. The purpose of this study was to identify the needs for vocational training that nursing Shkodra need to handle psychologically their patients where specifically the main goal is to recognize the level of practical skills adviser to the profession of a nurse, techniques, application of these skills in hospital settings. Results of the study reported that about $63.3 \%$ of subject report that they are trained on the techniques of psychological counseling, about $18.5 \%$ of the subjects are familiar with these training through scientific articles, about $41.1 \%$, through announcements made by the Directorate of Public Health, $18.5 \%$, via the internet, $16.1 \%$ are recognized through curricula, $5.6 \%$ through newspapers. And $87.4 \%$ of subjects were equipped with skills and techniques to handle the emotional state of patients or their families, while $12.6 \%$ report that these exercises are not equipped with these skills, as about $90.7 \%$ of the sample report that would have liked to be trained to enhance their professional skills in dealing with emotional concerns etc.

Keywords: Psychology, skills, training, professional development, communication, general practitioners, nurses

\section{Introduction}

There is a serious shortage of well-trained to employees of nursing, and this situation is creating severe difficulties in the delivery of high-quality psychological service. Techniques for psychologically-informed practice are diverse in themselves, and recommendations to improve care have included developing communication skills, cultural sensitivity and interpersonal interactions to name but a few. In addition to these abilities, the rapidly-expanding evidence base of diagnoses and their treatments creates a need to regularly update healthcare professionals' own psychological knowledge. 'Education, training, and development' are regularly acknowledged as the preferred way to enhance skill acquisition, and more frequently the only way to improve patient care in this context (Department of Health, 2013).

The need for training is a concept that is quoted in an ongoing but very rarely recommend how it should be. Numerous issues facing health workers especially nurses lead to the birth of the need for their participation in appropriate training that make them better able to handle situations of patients who go to great psychological burden.

The purpose of psychological professional development is to improve patient outcomes; therefore it is necessary to gain practical knowledge for the profession of nurses to affect patients effectively. However, there are relatively few studies that determine the effective training of personnel psychological health.

During the past decades, advanced practice nurse roles have been successfully established (e.g., in the USA, Canada, Great Britain, Holland, in Zealand, and Australia). The advanced practice nurse role includes educational advancement, specialization, and role expansion (Harmic) and is shaped by country and context specific characteristics (Wong, 2008). Nurses who successfully train and practice their roles are constantly in a process of maturity enabling equipping them with skills in order to rate the patients' holistic. A recent Nordic study also revealed that top-level managers and politicians emphasize that the acute and complex needs of ill people will require nurses who possess an advanced competence, relative to both medical treatment and psychological nursing care (Finnbakk, Skovdahl, Fagerstrwm, 2012). After a brief description of the theoretical baths are needed to be presented and the objective of this study which was: identification of vocational training needs that nursin Shkodra can handle psychologically their patients where more specifically key goal was the knowledge level of practical skills to the profession of nurse counseling techniques, the application of these skills in hospital settings.

\section{METHODOLOGY}




\section{Participants}

Participated in this study, 201 nurses and nursing students of the city of Shkodra. The statistical data report that about $86.7 \%$ of participants in the study were female and $13.3 \%$ male, $97.7 \%$ are over age group $20-29$ years, $11.6 \%$ were aged $30-39,4.3 \%$ are aged $40-49$ years, $2.9 \%$ are 50 and older. About $51.6 \%$ have higher education, $31.9 \%$ have a master, and $2.2 \%$ have doctorate education level. About $60 \%$ of participants turns out to have 0 -years of work, $8.1 \%$ appears to have $1-5$ years of work, $9.3 \%$ appears to have $6-11$ years of work, it appears that $12.8 \%$ work $12-17$ years, and $5.8 \%$ it turns out to have more than 18 years of work.

\section{Table 1. Socio-demographic characteristics of all study participants.}

\begin{tabular}{|l|l|l|l|}
\hline $\begin{array}{l}\text { Demographic } \\
\text { characteristics }\end{array}$ & \multicolumn{2}{|l|}{$\begin{array}{l}\text { Sex of respondent } \\
\text { Male (\%) Female (\%) Total }\end{array}$} & 201 \\
\hline All respondents & $33(13,3)$ & $159(86.7)$ & \\
Age & $12(57.1)$ & $118(83.1)$ & \\
$21-31$ & $6(28.6)$ & $14(9.9)$ & \\
$32-42$ & $3(14.3)$ & $4(2.8)$ & \\
$43-53$ & $12(51.6)$ & $2(1.4)$ & \\
$54-65$ & $18(31.9)$ & $81(50.9)$ & \\
Educational level & $3(2.2)$ & $60(37.7)$ & \\
Bachelor & $3(10)$ & $14(8.8)$ & \\
Msc & $6(20)$ & $100(65.4)$ & \\
Phd & $12(40)$ & $9(5.9)$ & \\
work experience & $3(10)$ & $25(16.3)$ & \\
0 years & $6(20)$ & $9(5.9)$ & \\
1-5 & & & \\
$6-11$ & & & \\
$12-17$ & & & \\
More than 18 & & & \\
\hline
\end{tabular}

\section{Measures}

It is used a questionnaire in this study: Clinical powers to nurses (NCCS) Nieminen and Fagerstrom 2005. Nurse Clinical Competence Scale Based on ICN: definition of Nurse Practitioners i.e.: the expert knowledge base, complex decisionmaking skills and clinical competencies for expanded practice example of items to be assessed: -I take responsibility for my own actions -I work independently $-\mathrm{I}$ am systematic in my way of working $-\mathrm{I}$ am self-critical about my way of working -I conduct physical assessment of the patient -I have independent responsibility for the examination, care and treatment of patients with complicated- and uncomplicated illness - I provide individual advice on health promotion and illness prevention to the patient, taking national recommendations into consideration -I take active responsibility for my own professional development.

\section{Research question:}

How is the level of competences to nurses to carry out psychological counseling to their patients?

\section{Hypothesis:}

The level of competence of exercising psychological consulting skills to nurses is high.

\section{Data management and analysis}

The analysis of this research was performed by statistical Package for Social Sciences (SPSS) version 21. Descriptive analysis as well as analytical Was employed to Determine psychological level vocational training which are equipped nursing students and nurses of the city of Shkodra. The results are presented in statistical way according to some demographic data.

\section{Results}

The statistical data about the training received during the last 3-5 years on techniques of psychological counseling to students and teachers report that $63.3 \%$ of subjects were trained on techniques of psychological counseling during the last $3-5$ years, also around $36.7 \%$ they are not trained in the techniques of psychological counseling during the last 3-5 years. 
Statistical data derived from descriptive analysis about the manner of obtaining information about the training techniques of psychological counseling report that $18.5 \%$ of the subjects are familiar with these training through scientific articles, about $41.1 \%$ through announcements made by the Department of Public Health, $18.5 \%$ via the internet, $16.1 \%$ are recognized learning through curricula, 5.6\% are known through newspapers.

The results of the question: during training made part of the training has been a device with practical skills and techniques advised to treat emotional or psychological patients, their relatives, etc.? Reported that $87.4 \%$ of subjects were equipped with skills and techniques to handle the emotional state of patients or their families, while $12.6 \%$ report that these exercises are not equipped with these skills. Details about the need to have this category for obtaining training to support their professional practice primarily in the treatment of emotional distress report that $90.7 \%$ would be like to be trained to enhance their professional skills and $12.6 \%$ report that they would not They wish to train.

The results of the level of ability that these entities to advise patients about their concerns psychological and emotional results show that $65.7 \%$ of respondents think that they are able to advise psychologically their patients, $17.4 \%$ think that they are not able to handle psychologically patients about their concerns. Results arising in connection with counseling techniques that use respondents in their work with patients reporting that $4.9 \%$ interact with their patients, $24.3 \%$ report that they listen carefully to their patients about the concerns, $17.5 \%$ try to be empathetic, $3.9 \%$ report that they offer continuous support patients, $1.9 \%$ try to alleviate emotional symptoms, $8.7 \%$ strive to continuously encourage their patients, $20.4 \%$ encourage their patients to speak openly in about emotional concerns that they may have $2.9 \%$ report that they try to reduce the level of stress and anxiety in patients, $3.9 \%$ up trying to raise the morale of patients, $5.8 \%$ try to provide a better environment, comfort, try $3.9 \%$ increase the level of positive emotions of patients, $1.9 \%$ and to help their patients to remain calm. (See table 2).

\begin{tabular}{|c|c|c|}
\hline $\begin{array}{l}\text { Received training during the last 3-5 years of psychological } \\
\text { counseling techniques. }\end{array}$ & $\begin{array}{l}\text { Yes \% } \\
119(63.3)\end{array}$ & $\begin{array}{l}\text { No } \% \\
69(36.7)\end{array}$ \\
\hline $\begin{array}{l}\text { Ways of getting information about the training techniques of } \\
\text { psychological counseling }\end{array}$ & $\begin{array}{l}\text { scientific articles Staff from DFS Website } \\
\text { curriculum Newspaper }\end{array}$ & $\begin{array}{l}23(18.5) \\
51(41.1) \\
23(18.5) \\
20(16.1) \\
7(5.6)\end{array}$ \\
\hline $\begin{array}{l}\text { Asked during training, the training part was a device with } \\
\text { practical skills and techniques to advise psychological or } \\
\text { emotional treat patients, to their relatives, etc.? }\end{array}$ & $\begin{array}{l}\text { Yes \% } \\
159(87.4)\end{array}$ & $\begin{array}{l}\text { No } \% \\
23(12.6)\end{array}$ \\
\hline $\begin{array}{l}\text { You would like to have the opportunity to receive training, } \\
\text { which focus specifically on increasing the skills to deal with } \\
\text { emotional distress? }\end{array}$ & $\begin{array}{l}\text { Yes \% } \\
165(90.7)\end{array}$ & $\begin{array}{l}\text { No } \% \\
17(9.3)\end{array}$ \\
\hline $\begin{array}{l}\text { Do you think you are capable or prepared psychologically } \\
\text { professionally to advice patients about their concerns? }\end{array}$ & $\begin{array}{l}\text { Yes \% } \\
132(65.7)\end{array}$ & $\begin{array}{l}\text { No } \% \\
35(17.4)\end{array}$ \\
\hline $\begin{array}{l}\text { What are the psychological techniques to use during your } \\
\text { work with patients? }\end{array}$ & $\begin{array}{l}\text { Conversation } \\
\text { Patient listening carefully } \\
\text { Being empathic } \\
\text { Continued provision of support } \\
\text { Emotional symptom relief } \\
\text { Encourage continuous patient }\end{array}$ & $\begin{array}{l}5(4.9) \\
25(24.3) \\
18(17.5) \\
4(3.9) \\
2(1.9) \\
9(8.7)\end{array}$ \\
\hline
\end{tabular}




\begin{tabular}{|l|l|l|}
\hline & Promoting an open communication & $21(20.4)$ \\
& Stress reduction in anxiety symptoms. & $3(2.9)$ \\
& & $6(5.8)$ \\
& & $4(3.9)$ \\
& & $2(3.9)$ \\
\hline
\end{tabular}

\section{Discussion}

The Findings of the study equipped Was psychological counseling techniques. Information about the organization of such training is generally received more training that organizes the Regional Directorate of Public Health in Shkodra.

Nursing students and nurses of the city of Shkodra expressed the wish to participate in training that help enhance their professional skills especially in the training main objective is giving them the skills counseling, they also see themselves capable to treat patients using psychological counseling techniques.

In connection with the techniques that they use to treat their patients psychologically they report results used the some practical techniques which in some way may help their patients to be more calm their emotional. Results of the study generated a confirmation of the hypothesis report filed by the researcher. The data derived from this study are now declined with other studies that also suggest that students and employees of nursing participated in vocational training among other things, part of these trainings are very effective to improve the professional skills of employees health, and this effect increases when these skills to achieve desired results in patients.

In a study conducted by Hollimworth and Hawinks attended by 39 nurses results showed that nurses who had undergone intensive training to improve their skills consulting in the exercise of their profession, were found to be better able to handle their patients with psychological disorders. After the training there was a difference in understanding and providing psychological support. While the group of nurses who did not participate in this training were unable or unwilling to apply the skills of counseling care.

This highlights the need to address nurses' attitudes and beliefs that may interfere with psychological support for patients with various emotional difficulties (Hollimworth and Hawinks, 2002). Increased professional training tailored to the specific needs of professional nurses can positively influence the growth of professional skills of these employees. Results of the study provide a brief overview about the level of psychological counseling skills to benefit from various professional training to students and the city of Shkodra nurses.

Realizing the importance of this study was associated with the identification of needs for the implementation of professional training in accordance with the objectives of the work of these employees. Results of the study though, may be modest groundwork for a future work with the aim that can be expanded and the inclusion of a representative sample with.

The results can be generalized only to be included in the study sample, but can be reversed by researchers who want to submit similar data. It is important to get to know the limitations of this study.

- First limitation associated with the selected method and questionnaire for this study

- Second limitation is related to the number of participants in the study which it can't be generalizing

and in a group or similar populations.

\section{References}

[1] Akamine I, Uza M, Shinjo M, Nakamori E. Development of competence scale for senior clinical nurses. Jpn J Nurs Sci. 2013; 10(1):55-67. doe: 10.1111/j.1742-7924.2012.00210.x. [PubMed] [Cross Ref]

[2] Sheer B, Wong FK J Nurse Scholars. 2008; 40(3):204-11. The development of advanced nursing practice globally. 
[3] Hamric AB. A Definition of Advanced Practice Nursing. In: Homeric AB, Spiros JA, Hanson CM, editors. Advanced practice nursing. An integrative Approach 4th edition. St Louis: Saunders Elsevier Inc; 2009. pp. 75-94.

[4] Finnbakk E, Skovdahl K, Stwre Blix E, Fagerstrwm L. Top-level mangers' and politicians' worries about future care for older people with complex and acute illnesses - a Nordic study. Into J Older People Nurs.2012; 7(2):163-172. doe: 10.1111/j.1748-3743.2012.00312.x.

[5] Hollinworth H, Hawkins J. Teaching nurses psychological support of patients with wounds. Br J Nurs. 2002 Nov; 11 (20 Supple): S8, S10-S12, S14, S16, S18.

[6] World Health Organization. Web Site: 10 facts on patient safety. Updated June 2014. [http://www.who.int/features/factfiles/patient_safety/en/]. Accessed 15 March 2013.

[7] Web-reference:

[8] https://www.gov.uk/government/publications/department-of-health-corporate-

[9] Plan-2013-14/department-of-health-2013-14-corporate-plan 